\title{
Electrocatalytic Oxidation of Nitric Oxide at Carbon Paste Electrode Modified with Chromium (III) Oxide
}

\author{
Liridon S. Berisha ${ }^{1}$, Kurt Kalcher ${ }^{2}$, Arsim Maloku ${ }^{1}$, Eduard Andoni ${ }^{3}$, Tahir Arbneshi ${ }^{1}$ \\ 'Departament of Chemistry, Faculty of Mathematical and Natural Science, University "Hasan Prishtina", \\ Prishtina, Kosovo \\ liridon.berisha@uni-pr.edu \\ a.maloku@hotmail.com \\ tahir.arbneshi@uni-pr.edu \\ ${ }^{2}$ Institute of Chemistry, Analytical Chemistry, Karl-Franzens University Graz, Graz, Austria \\ kurt.kalcheri@uni-graz.edu \\ ${ }^{3}$ Departament of Chemistry, Faculty of Natural Sciences, University of Tirana, Tirana Albania \\ eduard.andoni@fshn.edu.al
}

\begin{abstract}
Chromium (III) oxide was used as a bulk mediator in carbon paste electrodes to improve the better performance of the carbon electrodes for the detection of nitric oxide in comparison with unmodified electrodes. The reaction mechanism of the electrocatalytic oxidation of $\mathrm{NO}$ at the modified electrode was studied using cyclic voltammetry and differential pulse voltammetry. The chemical sensor could be operated under physiological conditions ( $\mathrm{pH} 7.5,0.1 \mathrm{M}$ phosphate buffer), with an operating potential of $750 \mathrm{mV}$ (vs. $\mathrm{Ag} / \mathrm{AgCl}$ ), in hydrodynamic amperometry. The amperometric response of the sensor showed good linearity up to $200 \mu \mathrm{mol} / \mathrm{L}$ with a detection limit $(3 \sigma)$ of $0.69 \mu \mathrm{mol} / \mathrm{L}$. The effect of the interferent nitrite was not fatal and could be eliminated by the use of the standard addition method. The new chemical sensor seems also promising to detect $\mathrm{NO}$ in car exhaust fumes.
\end{abstract}

Keywords:Sensor; Nitric Oxide; Chromium (III) oxide; Electrocatalytic; Carbon Paste electrode.

\section{Academic Discipline And Sub-Disciplines}

Chemistry -Electroanalytical chemistry

\section{SUBJECT CLASSIFICATION}

chemistry

\section{TYPE (METHOD/APPROACH)}

Experimental

\section{Council for Innovative Research}

Peer Review Research Publishing System

Journal: Journal of Advances in Chemistry

Vol. 5, No. 3

editor@cirworld.com

www.cirworld.com, member.cirworld.com 


\section{INTRODUCTION}

Nitric oxide is implicated in a wide range of physiological and pathophysiological effects. Some of its physiological functions are smooth muscle relaxation, inhibition of platelet activation, neurotransmission, immune response [1] and also in $\beta$-cells destruction during development of insulin dependent diabetes mellitus (type I) [2].

Determination of $\mathrm{NO}$ is not a simple task because of its high reactivity; the half-life of nitric oxide in physiological conditions is around 5 seconds; therefore the required analytical methods for its spatial detection have to have rapid response time [3].

The development of electrochemical sensors for the determination of NO in biological fluids is significant for the diagnosis and management of metabolic diseases. Compared to electrochemical sensors, spectroscopic methods are very useful for the determination of $\mathrm{NO}$ but they suffer from different components which are present in biological fluids. Electrochemical sensors can measure NO directly in real time also in vivo, because they can be implanted as micro-sized probes [4].

Most of the investigations are focused on electrochemical sensors because of their easy applicability and low cost. Carbon paste electrode as an electrochemical sensing material has a lot of advantages including simple preparation and modification, as well as ease to handle. They also have a wide applicable potential range, which makes them very useful in electrochemical analysis for different analytes [5] and are applicable for in vivo measurements [6].

Nitric oxide can be detected with chemically modified carbon paste electrodes at lower potentials which makes them useful in biological media without significant interference from the sample matrix. Different modifiers were investigated on their ability to decrease the overpotential of nitric oxide on different electrode materials, such as nickel phtalocyanine which has a catalytic effect on the NO oxidation $[7,8]$. Decreasing the overpotential is important because at higher potentials possible interferents present in sample may be oxidized as well. The product of NO oxidation are nitrite and nitrate ions, from which the former may interfere with the determination of NO [9]. Using different polymers such as ophenylendiamine [10], poly(thionine) and Nafion [11] the selectivity of sensors was increased and could be employed for NO monitoring in rat kidneys.

Because of its catalytic effect on the oxidation of NO, a nickel hexacyanoferrate-modified electrode could be operated at a potential of $+0.40 \mathrm{~V}$ vs. $\mathrm{Ag} / \mathrm{AgCl}[12]$, and an indium hexacyanoferrate analogue at $+0.75 \mathrm{~V}$ vs. SCE $[13]$. Also $\mathrm{RuO}_{2}$ was found suitable for carbon paste modification for the quantification of NO [14].

The study presented here is focused on the possibilities of carbon-based heterogeneous electrodes modified with chromium (III) oxide for the detection of nitric oxide and its eventual application as amperometric sensor.

\section{EXPERIMENTAL}

\subsection{Chemicals, Reagent and Solutions}

All chemicals used were of analytical reagent grade. Sulfanilamide, N-(1-naphtyl)-ethylene diamine were obtained from Sigma Aldrich and chromium (III) oxide was purchased from Fluka. Phosphate buffer solution (PBS) was prepared by mixing aqueous solutions of sodium dihydrogen phosphate $(0.1 \mathrm{~mol} / \mathrm{L})$ and disodium hydrogen phosphate $(0.1 \mathrm{~mol} / \mathrm{L}) \mathrm{unti}$ the required $\mathrm{pH}$ was achieved.

A nitric oxide stock solution was prepared by bubbling NO produced by the reaction of a saturated aqueous solution of sodium nitrite with $2 \mathrm{M}$ sulfuric acid through a $4 \mathrm{M}$ potassium hydroxide solution and finally collecting it in phosphate buffer solution $(0.1 \mathrm{M}, \mathrm{pH} 7.5)$. All the apparatus for $\mathrm{NO}$ gas production first was de-aerated with nitrogen gas for 30 minutes. The standard stock solution was freshly prepared before use. The concentration of NO in the stock solution was determined using sulfanilamide and $\mathrm{N}$-(1-naphtyl)-ethylenediamine as described in [15].

Sodium nitrite and nitrate stock solution $(0.1 \mathrm{M})$ were freshly prepared be- fore use.

\subsection{Aparatus}

For cyclic voltammetry and hydrodynamic amperometry, a potentiostat Autolab PSTAT 10 with software GPES version 4.9 and a potentiostat PalmSens with software PSTrace were used. The electrochemical cell consisted of a carbon paste electrode as the working electrode, an $\mathrm{Ag} / \mathrm{AgCl} / 3 \mathrm{M} \mathrm{KCl}$ reference electrode (Metrohm 6.0733.100), and a platinum wire as the counter electrode. Nitrogen was used for degassing the solutions. A magnetic stirrer provided convection of the solution. All potentials mentioned in this paper are referred to the $\mathrm{Ag} / \mathrm{AgCl}$ reference electrode.

\subsubsection{Preparation of working electrode}

Unmodified carbon paste was prepared by mixing $1.000 \mathrm{~g}$ graphite powder and $360 \mu \mathrm{L}$ paraffin oil (Uvasol $($, $0.84-0.89$ $\mathrm{kg} / \mathrm{L}$,) in an agate mortar by gently stirring with a pestle until uniformity and proper compactness was obtained.

The modified carbon paste was prepared by mixing $0.950 \mathrm{~g}$ graphite powder with $0.050 \mathrm{~g} \mathrm{Cr}_{2} \mathrm{O}_{3}$ and $360 \mu \mathrm{L}$ paraffin oil. The carbon pastes were transferred to glass vials and allowed to stand overnight in a refrigerator.

\subsubsection{Procedures}

Cyclic voltammograms were scanned between $-400 \mathrm{mV}$ and $+1200 \mathrm{mV}$ with a scan rate of $20 \mathrm{mV} / \mathrm{s}$, unless stated otherwise. Experimental parameters during differential pulse voltammetry measurements were recorded with a pulse amplitude of $50 \mathrm{mV}$ and scanned in two ways from $200 \mathrm{mV}$ until $-1300 \mathrm{mV}$ and $-200 \mathrm{mV}$ until $-1200 \mathrm{mV}$. Hydrodynamic 
amperometric measurements were made at operating potentials of $+550 \mathrm{mV}, 600 \mathrm{mV}, 650 \mathrm{mV}, 700 \mathrm{mV}$ and $750 \mathrm{mV}$ if not mentioned otherwise; NO stock solution $(0.50-4.00 \mathrm{~mL})$ was added per step.

\section{RESULTS AND DISCUSSION}

A modified carbon paste electrode modified with chromium (III) oxide was studied for its effect on the electrochemical behavior on the detection of nitrogen oxide.

The effect of the modifier in carbon paste was studied with cyclic voltammetry. Figure 1 shows the cyclic voltammogram of $\mathrm{NO}$ with a plain carbon paste electrode in phosphate buffer. At negative potentials practically no difference to the blank can be noticed. At positive potentials the oxidation of $\mathrm{NO}$ occurs, probably to $\mathrm{NO}_{2}^{-}$or $\mathrm{NO}_{3}{ }^{-}$with a peak potential above $1.10 \mathrm{~V}$. With the unmodified electrode the electrochemical activity of nitrite was tested (Fig.2). It yields a signal in the same potential region as nitrogen oxide but its concentration $(1 \mathrm{mM})$ must be some 20 times higher than NO to provide a similar current (around $25 \mu \mathrm{A}$ at $1.0 \mathrm{~V}$ ). At this potential $(1.0 \mathrm{~V})$ oxidation of $\mathrm{NO}_{2}^{-}$occurrs probably to $\mathrm{NO}_{3}^{-}$[16, 17]. According to this, we can conclude that nitric oxide is going to be oxidized at that potential to form finally $\mathrm{NO}_{3}^{-}$via formation of nitrite.

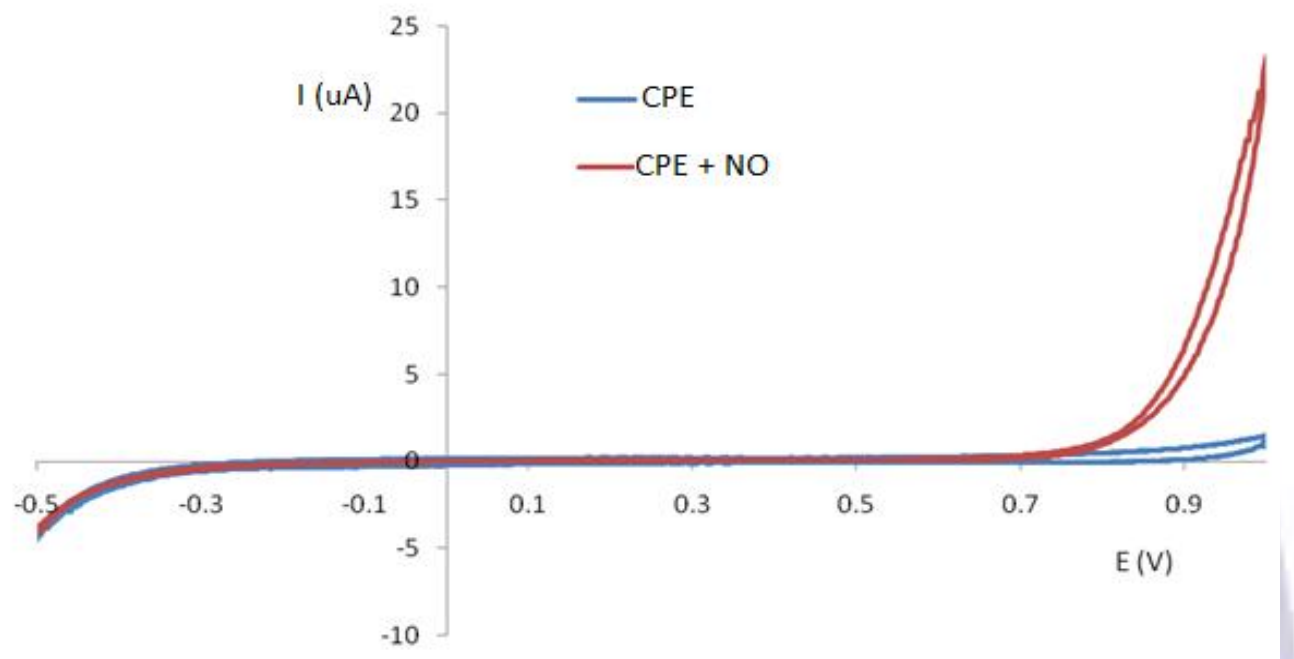

Figure 1. Cyclic voltammograms of a plain CPE before and after the addition of $50 \mu \mathrm{mol} / \mathrm{L} \mathrm{NO}$, scan rate $20 \mathrm{mV} / \mathrm{s}$, Einit. $=-0.50 \mathrm{~V}$, Efinal $=1.00 \mathrm{~V}$; phosphate buffer $0.1 \mathrm{M}, \mathrm{pH} 7.5$.

No significant difference was noticed between the modified and the unmodified electrode in cyclic voltamograms scanned in phosphate buffer $(0.1 \mathrm{M}, \mathrm{pH} 7.5)$ in the absence of NO. Figure 3 displays cyclic voltamograms of carbon paste modified with chromium (III) oxide after addition of nitric oxide $(50 \mu \mathrm{M})$ and sodium nitrite $(1 \mathrm{mM})$. In the negative potential range no redox peak of $\mathrm{NO}$ or nitrite can be seen whereas oxidation of $\mathrm{NO}$ and $\mathrm{NO}_{2}$ occurs at around $1.0 \mathrm{~V}$. At the modified electrode the voltammogram in anodic direction exhibits oxidation of nitrogen oxide starting at $0.6 \mathrm{~V}$ with a shoulder at 0.7 $\mathrm{V}$ and a maximum at around $1.0 \mathrm{~V}$. Thus, it may be concluded that chromium (III) oxide has a significant effect on the analytical signal of the analyte and is well suitable for its mediated detection.

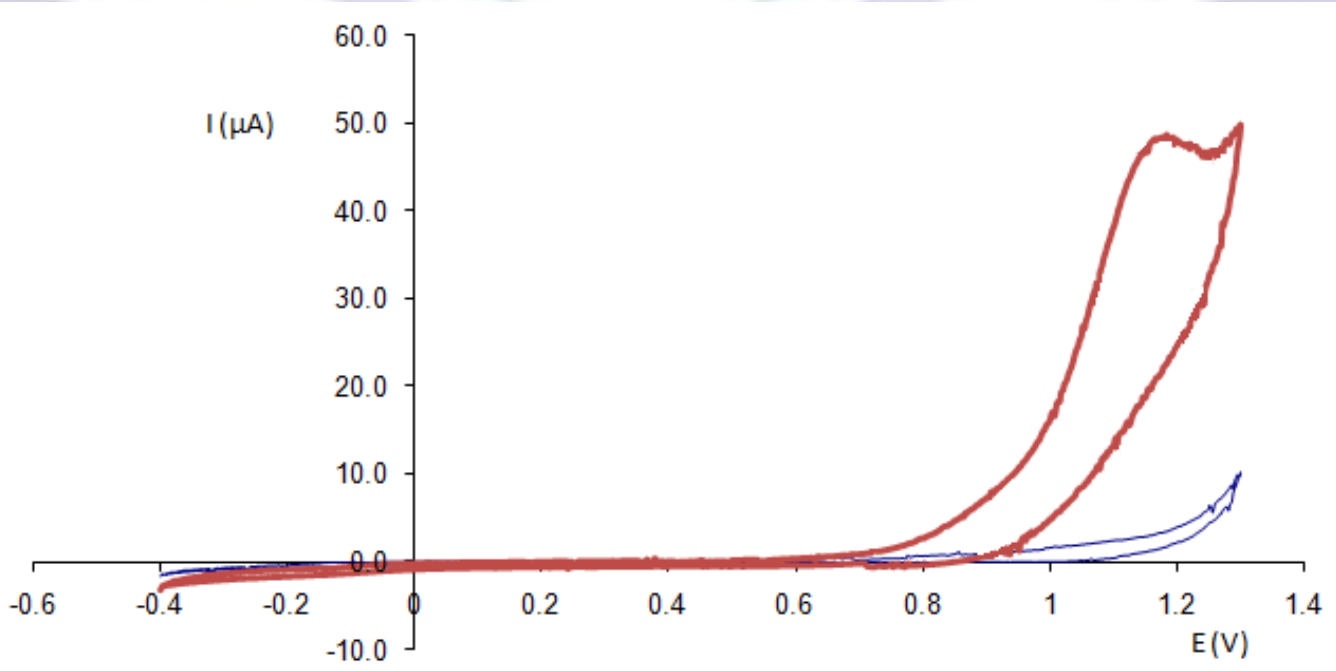

Figure 2. Cyclic voltammograms of a plain CPE before and after the addition of $1 \mathrm{mmol} / \mathrm{L} \mathrm{NaNO}_{2}, \mathrm{scan}$ rate $20 \mathrm{mV} / \mathrm{s}$, Einit. $=-0.40 \mathrm{~V}$, Efinal $=1.30 \mathrm{~V}$; phosphate buffer $0.1 \mathrm{M}$, pH 7.5. 


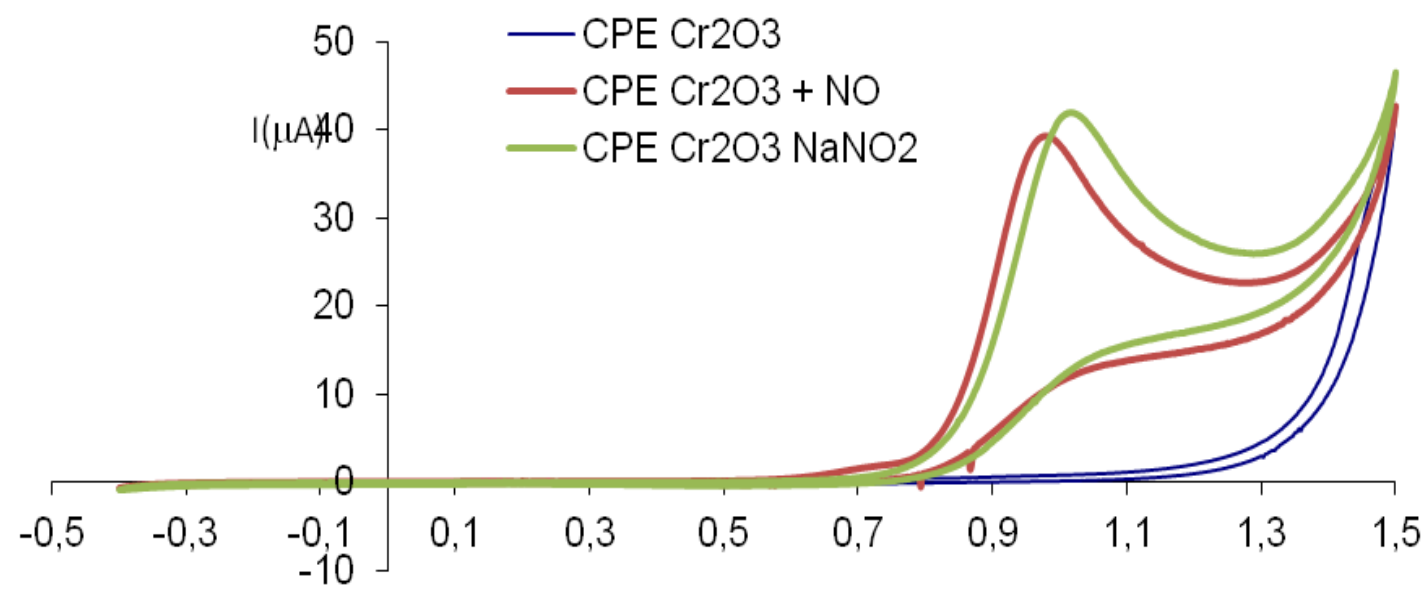

Figure 3. Cyclic voltammograms of a modified $\mathrm{CPE}$ with $\mathrm{Cr}_{2} \mathrm{O}_{3}$ before and after the addition of $50 \mu \mathrm{mol} / \mathrm{L} \mathrm{NO}$ and $1 \mathrm{Mm} \mathrm{NaNO} 2$ scan rate $20 \mathrm{mV} / \mathrm{s}$, Einit. $=-0.40 \mathrm{~V}$, Efinal $=1.50 \mathrm{~V}$; phosphate buffer 0.1 M, pH 7.5.

To evaluate more the reaction happening in the potential range 0.60 and $0.80 \mathrm{~V}$ differential pulse voltammetry was used (Fig.4). Carbon paste electrodes modified with chromium (III) oxide showed a current response at a potential of around $0.70 \mathrm{~V}$ which corresponds to the conversion of $\mathrm{Cr}$ (III) to a higher oxidation state.

After addition of nitric oxide to the solution the oxidation peak of chromium and nitric oxide are superimposed. The peak intensity are proportional to concentration of nitric oxide in the solution.

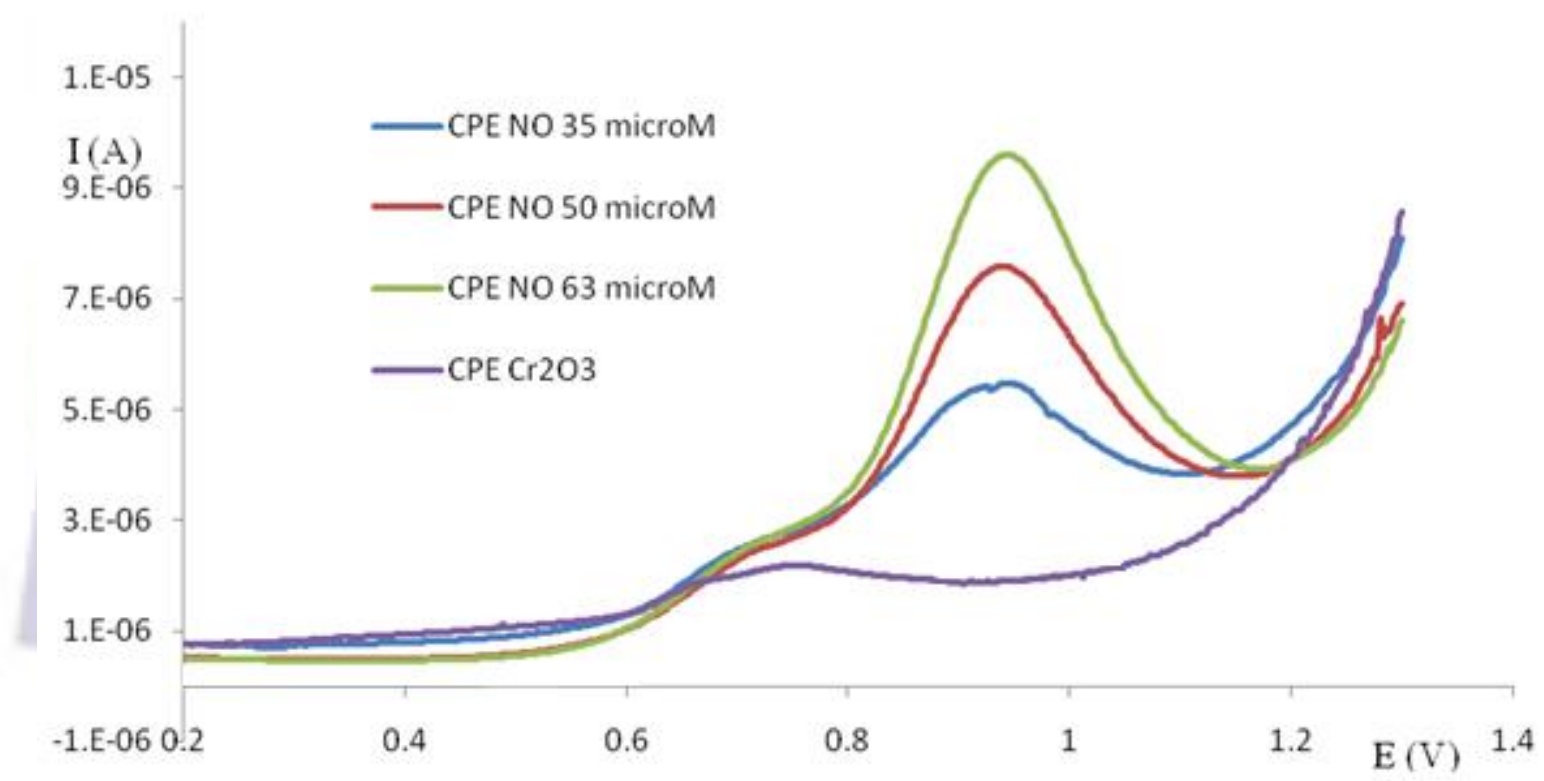

Figure 4. Differential pulse voltammograms of a modified $\mathrm{CPE}$ with $\mathrm{Cr}_{2} \mathrm{O}_{3}$ before and after the addition of 35, 50, $63 \mu \mathrm{mol} / \mathrm{L}$ NO, modulation amplitude $0.05 \mathrm{~V}$, step potential $2.44 \mathrm{mV}$, Estart $=0.20 \mathrm{~V}$, Efinal $=1.30 \mathrm{~V}$; phosphate buffer $0.1 \mathrm{M}$, pH 7.5. (Electrode surface $1 / 2$ of CPE)

Based on the observations obtained from the cyclic and differential pulse voltammograms, a reaction mechanism is suggested which explains the electrocatalytic behavior of chromium (III) oxide. $\mathrm{Cr}_{2} \mathrm{O}_{3}$ contains chromium in the oxidation state III; and by electrochemical oxidation to $\mathrm{Cr}(\mathrm{VI})$ further oxidize nitric oxide to higher oxidation states. As the signal for the oxidation of chromium $(0.7 \mathrm{~V})$ is not afeected directly, but a strongly increased current occurs at around $0.95 \mathrm{~V}$ (oxidation potential of $\mathrm{NO}_{2}^{-}$) it is assumed that the reaction product between $\mathrm{Cr}(\mathrm{VI})$ and $\mathrm{NO}$ is primarily nitrite which is further oxidized to nitrate.

Chromium (VI) generated electrochemically is reduced by nitric oxide again to $\mathrm{Cr}(\mathrm{III})$ sustaining the "electrocatalytic" mediating cycle.

Thus the action of the mediator on the oxidation of nitric oxide may be sketched as shown in Figure 5. 
Primarily chemical oxidation of $\mathrm{Cr}(\mathrm{III})$ from $\mathrm{Cr}_{2} \mathrm{O}_{3}$ to probably $\mathrm{Cr}(\mathrm{VI})$ occurs, which in turn is reduced chemically to chromium(III) by the analyte. The latter is oxidized chemically to nitrite which is further oxidized to nitrate. The resulting chromium (III) is also electrochemically converted to $\mathrm{Cr}(\mathrm{VI})$ again. At potentials around $0.95 \mathrm{~V}$ the oxidation current in the voltammetric curves reflect the concentration of nitric oxide (via nitrite) already in the medium $\mu \mathrm{mol} / \mathrm{L}$ range. The suggested reaction mechanism is supported also by measurements in DPV mode in the negative potential range with carbon paste electrode modified with $\mathrm{Cr}_{2} \mathrm{O}_{3}$ (not shown). At $-0.85 \mathrm{~V}$ reduction of chromium $(\mathrm{VI})$ occurs and after addition of $\mathrm{NO}$ to the solution the peak intensity is decreased after every addition.

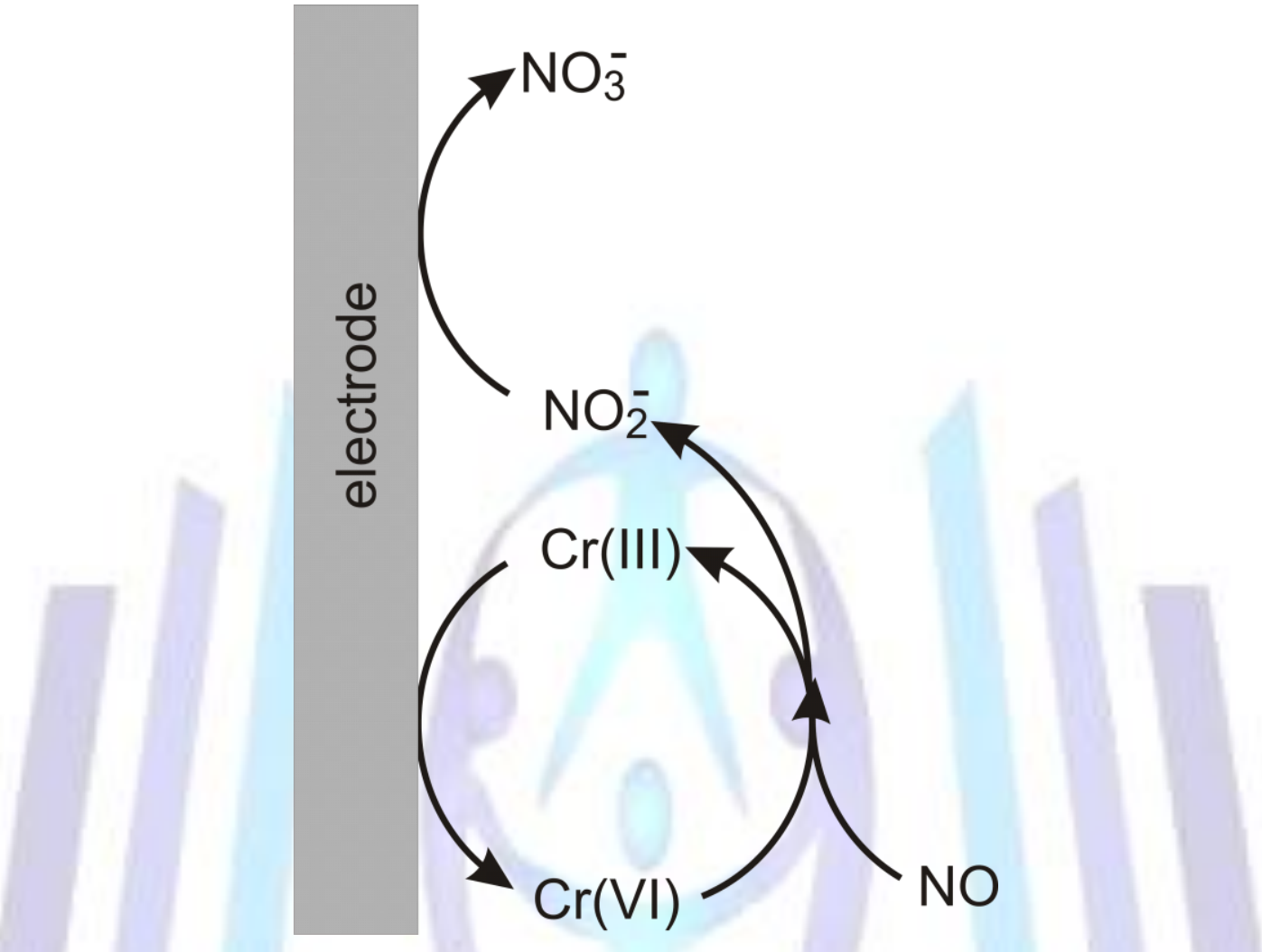

Figure 5. Suggested reaction mechanism of the electro-catalytic action of chromium (III) oxide on nitric oxide

\subsection{Hydrodynamic amperometry}

Figure 6 shows a typical hydrodynamic amperogram for a carbon paste electrode modified with chromium (III) oxide after addition of certain amounts of nitric oxide with an operation potential of $800 \mathrm{mV}$. Around $20 \mu \mathrm{M}$ of nitric oxide produce clearly distinct current steps already. The noise is produced by the agitation of the solution. The response time of the sensors is rather quick; usually after two seconds the full signal has evolved including dispersion of the analyte in the measurement solution.

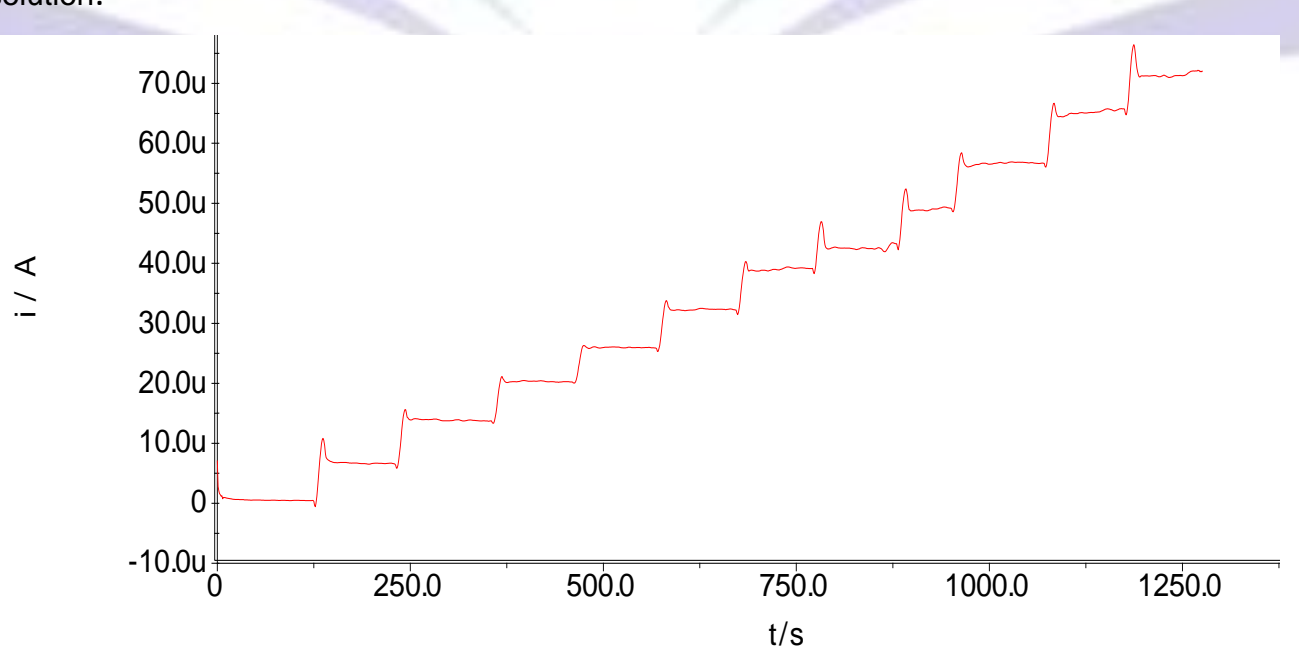

Figure 6. Hydrodynamic amperogram of modified $\mathrm{CPE}$ with $\mathrm{Cr}_{2} \mathrm{O}_{3}$ working potential $800 \mathrm{mV}$, addition $1 \mathrm{~mL}$ (NO $300 \mu \mathrm{M})$ per step into $15.0 \mathrm{~mL}$ phosphate buffer $(0.1 \mathrm{M}, \mathrm{pH}=7.5)$; stirred solution (approx. $300 \mathrm{rpm})$. 


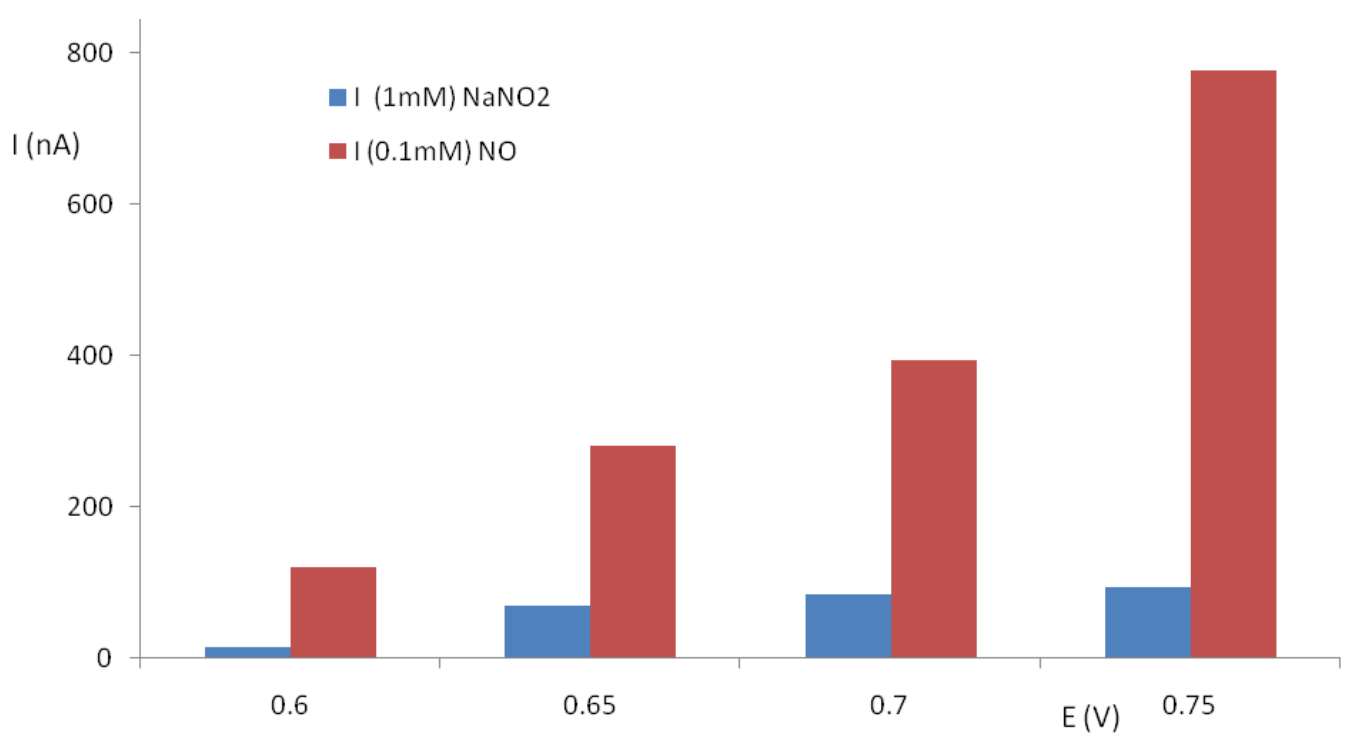

Figure 7. Hydrodynamic voltamperogram signal of nitric oxide and nitrite ion at a chromium (III) oxide modified carbon paste electrode; signal of the step in the hydrodynamic amperogram NO $100 \mu \mathrm{mol} / \mathrm{L} ;$ and $\mathrm{NaNO}_{2} 1000$ $\mu \mathrm{mol} / \mathrm{L}$.

In Figure 7 signals obtained for $\mathrm{NO}(100 \mu \mathrm{mol} / \mathrm{L})$; and $\mathrm{NaNO}_{2}(1000 \mu \mathrm{mol} / \mathrm{L})$ in the hydrodynamic amperometry for potentials from 0.60 to $0.75 \mathrm{~V}$ are compared. The signals for lower concentrations of $\mathrm{NO}$ are much higher than for nitrite, which documents that the chemical reaction between mediator and nitric oxide seems to be very efficient. Increasing the operation potential causes an increase of the oxidation current, but at the same time also the background current (current without nitric oxide) increases. Additionally, more positive potentials produce a drift of the baseline which deteriorates the repeatability, and also the lifetime of the sensor is reduced.

The operating potential is very important for practical applications of the sensor, because at higher values there is an increased risk for co-oxidation of other components from the sample matrix.

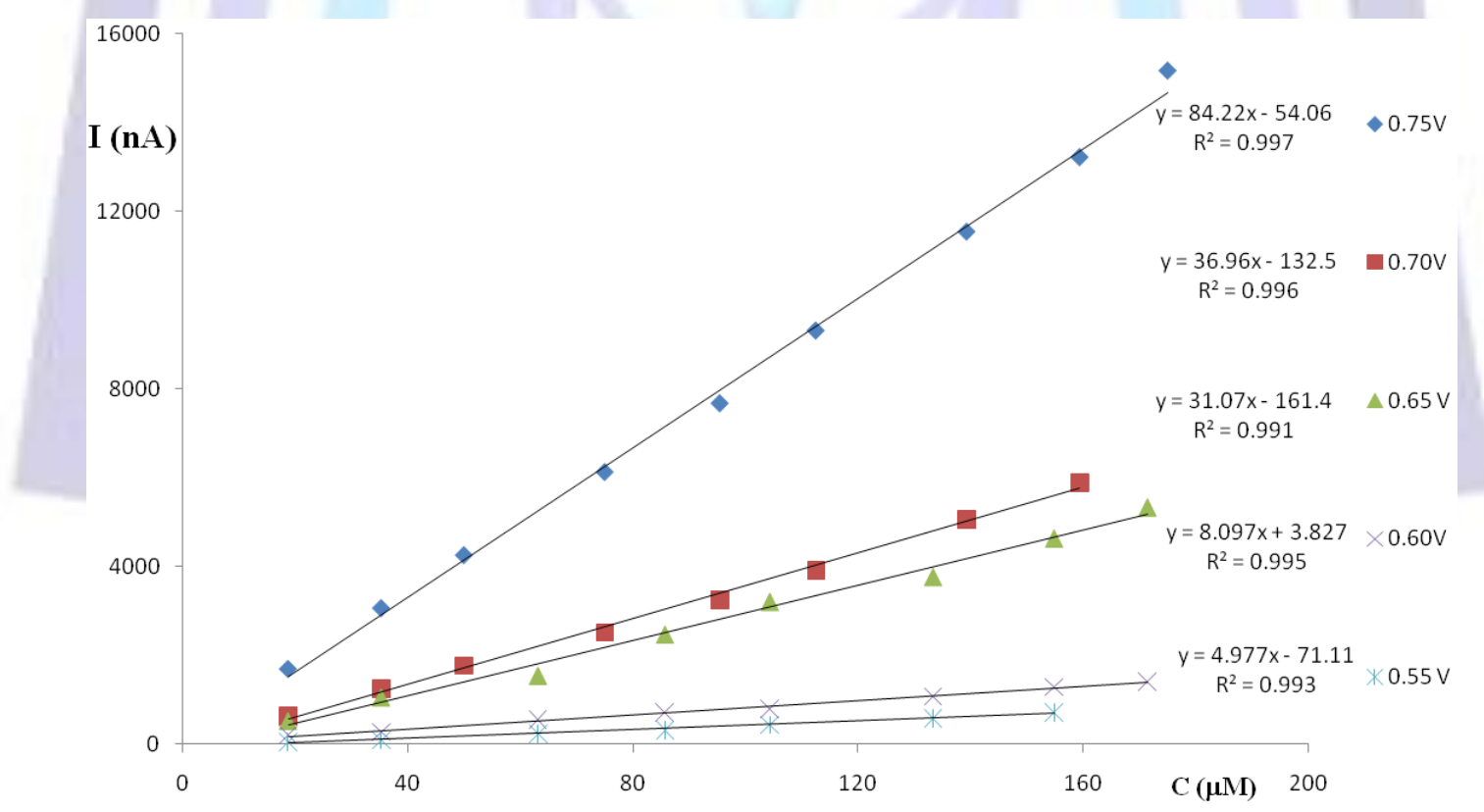

Figure 8. Hydrodynamic amperometric calibration curves for $\mathrm{NO}$ obtained with a $\mathrm{CPE}$ modified with $\mathrm{Cr}_{2} \mathrm{O}_{3}$ at various potentials

Calibration curves for different operating potentials, obtained from hydrodynamic studies, are summarized in Figure 8. In order to give an idea about the size of the background current, the latter was not subtracted from the signal but is represented as the intercept of the graph with the current axis at $\mathrm{C}=0 \mu \mathrm{mol} / \mathrm{L}$ of nitric oxide.

At all potentials above $550 \mathrm{mV}$ there is a quasi- linear relation between current and concentration of NO up to approximately $200 \mu \mathrm{mol} / \mathrm{L}$. At more positive potentials the electrode sensitivity is going to increase. Comparing the sensitivities of the electrode at different applied potentials, it can be seen that at $0.75 \mathrm{~V}$ it is roughly 10 times higher than at $0.60 \mathrm{~V}$ and around three times higher than at 0.65 and $0.70 \mathrm{~V}$. The sensitivity at $0,75 \mathrm{~V}$ is $84.22 \mathrm{nA} \cdot \mathrm{L} \cdot \mu \mathrm{mol}{ }^{-1}$. The operation 
potential of $0.75 \mathrm{~V}$ seems a bit high because electrochemical oxidation of sample matrix components may occur. Nevertheless, since nitrite seems to be the main interferent the ratios of the current responses are compared in Table 1.

Table 1. Signal ratios of nitric oxide and nitrite ion at a chromium (III) oxide modified carbon paste electrode, NO $100 \mu \mathrm{mol} / \mathrm{L} ;$ and $\mathrm{NaNO}_{2} 1000 \mu \mathrm{mol} / \mathrm{L}$.

\begin{tabular}{lccc}
\hline $\mathrm{E}(\mathrm{V})$ & $\mathbf{I} \mathbf{n A}$ & $\mathbf{I} \mathbf{n A}$ & $\mathbf{I}_{\mathrm{NO}} / \mathbf{I}_{\mathrm{NaNO} 2}$ \\
& $\left(1 \mathrm{mM} \mathrm{NaNO}_{2}\right)$ & $(0.1 \mathrm{mM}) \mathrm{NO}$ & \\
0.60 & 15 & 120 & 8.0 \\
0.65 & 70 & 281 & 4.0 \\
0.70 & 85 & 395 & 4.6 \\
0.75 & 95 & 777 & 8.2 \\
\hline
\end{tabular}

The interference signal in $0.75 \mathrm{~V}$ is not so high and can probably be removed using membranes which are permeable only for $\mathrm{NO}$; this is a subject of current investigations. On the other hand nitrite does not play any role with gaseous samples. Thus, $0.75 \mathrm{~V}$ seems to be a suitable operation potential for the determination of NO with a detection limit of $0.69 \mu \mathrm{mol} / \mathrm{L}$ $(\mathrm{SD}=1.2 \mathrm{nA}$, mean $82.3 \mathrm{nA}, \mathrm{n}=3)$.

\section{CONCLUSIONS}

The work presented here has clearly demonstrated that heterogeneous carbon sensors (carbon paste electrodes) with chromium (III) oxide as a mediator exhibit improved performance for the determination of nitric oxide compared to unmodified electrodes because the modifier lowers the over-potential and increases the sensitivity for the electrochemical oxidation of the analyte. The suggested reaction mechanism assumes the chemical reduction of chromium (VI) to chromium (III) by NO where the latter is oxidized to nitrite which in turn is oxidized to nitrate electrochemically.

The modified electrode has a good stability and high sensitivity which can be exploited for the determination of nitric oxide in hydrodynamic amperometry.

The new chemical sensor seems also promising to detect $\mathrm{NO}$ in car exhaust fumes.

\section{REFERENCES}

[1] Karen L. Davis, Emil Martin, Illarion V Turko, Ferid Murad, Annual Review of Pharmacology and Toxicology, 2001, Vol 41:203-236

[2] Jack Lancaster, Nitric oxide-principles and actions, 1996 Academic press, INC, London, pp.4-150

[3] Evan M. Hetrick, Mark H. Schoenfisch.Analytical chemistry of Nitric Oxide, Annual Review of Analytical Chemistry 2, pp.409-433 (2009)

[4] Xueji Zhang, Real time and in vivo monitoring of nitric oxide by electrochemical sensors-from dream to reality, Frontiers in Bioscience 9, pp.3434-3446 (2004)

[5] N. W. Beyene, P. Kotzian, K. Schachl, H. Alemuc, E. Tur- kušic, A. Copra, H. Moderegger, I. Švancara, K. Vytras and K. Kalcher, "(Bio)Sensors Based on Manganese Di- oxide-Modified Carbon Substrates: Retrospections, Further Improvements and Applications," Talanta, Vol. 64, No. 5, 2004, pp. 1151-1159.

[6] Ivan Svancara, Kurt Kalcher, Alain Walcarius, Karel Vytras. Electroanalysis with Carbon Paste Electrodes, CRC Press, USA 2012, pp.163

[7] Stéphane Trevin, Fethi Bedioui, Jacques Devynck, Electrochemical and spectrophotometric study of the behavior of electropolymerized nickel porphyrin films in the determination of nitric oxide in solucion, Talanta Vol. 43, Issue 3, 1996, pp 303-311.

[8] Barry W. Allen, Claude A. Piantadosi, Louis A. Coury. Electrode materials for nitric oxide detection, Nitric Oxide: Biology and Chemistry Vol. 4, No.1, pp.75-84 (2000)

[9] Fethi Bedioui, Sophie Griveau. Electrochemical detection of nitric oxide: Assessement of twenty years of strategies, Electroanalysis 24 pp.1-14 (2012)

[10] Marilyn N. Friedemann, Scott W. Robinson' Greg A. Gerhardt, o-Phenylenediamine-Modified Carbon Fiber Electrodes for the Detection of Nitric Oxide, Anal. Chem., 1996, 68 (15), pp 2621-2628.

[11] X. Chen, P. Xle, Q. Tian, S. Hu, Amperometric Nitric Oxide Sensor Based on Poly(Thionine)/Nafion-Modified Electrode and its Application in Monitorin Nitric Oxide Release from Rat Kidney, Analytical Letters (2006) Vol. 39 , 7 pp. 1321-1332. 
[12] A. Krylov, F. Lisdat, Nickel Hexacyanoferrate-Based Sensor Electrode for the Detection of Nitric Oxide at Low Potentials, Electroanalysis 2007, 19, No.1. pp 23-29.

[13] E. Casero, F. Pariente, E. Lorenzo, Electrocatalytic oxidation of nitric oxide at indium hexacyanoferrate filmmodified electrodes, Analyltical and Bioanalytical Chemistry (2003) 375 pp 294-299.

[14] PhD Thesis, W. Pubudu M. Peiris. New generation of electrochemical sensors for nitric oxide: ruthenium/carbonbased nanostructures and colloids as electrocatalytic platforms, Cleveland State University,August 2009

[15] R. Nims, J. Darbyshire, J. Saavedra, D. Christodoulou, I. Hanbauer, G. Cox, M. Grisham, F. Laval, J. Cox, M. Krishna, D. Wink, Methods: A Companion to Methods in Enzymology 7, pp.48-54 (1995).

[16] K. Kalcher; A New Method for the Voltammetric Determination of Nitrite. Talanta 33, 489-494 (1986).

[17] C.G.Neuhold, J.Wang, X.Cai, K.Kalcher, Screen-Printed Electrodes for Nitrite Based on Anion-Exchanger Doped Carbon Inks, Analyst, 120, 2377-2380 (1995). 